\title{
Comparative Analysis of Different Photovoltaic Simulation Software: Case Study on Analyzing the Performance of a 5,1 kWp Grid Connected Photovoltaic System
}

\author{
Feten Limem ${ }^{1}$, Serkan Sezen ${ }^{2 *}$ \\ ${ }^{1}$ Kocaeli University, Isntitute of Science, Departmant of Energy Systems Engineering, Kocaeli, Turkey, (ORCID: 0000-0001-8788-2912), feten92limem@gmail.com \\ ${ }^{2 *}$ Kocaeli University, Uzunçiftlik N. Ç. Voc. Sch., Departmant of Electric and Energy, Kocaeli, Turkey, (ORCID: 0000-0001-7273-7376), serkan.sezen@ kocaeli.edu.tr
}

(International Conference on Design, Research and Development (RDCONF) 2021 - 15-18 December 2021)

(DOI: $10.31590 /$ ejosat.1040126)

ATIF/REFERENCE: Limem, F., \& Sezen, S. (2021). Comparative Analysis of Different Photovoltaic Simulation Software: Case Study on Analyzing the Performance of a $5,1 \mathrm{kWp}$ Grid Connected Photovoltaic System. European Journal of Science and Technology, (32), 816-826.

\begin{abstract}
The high installation costs of photovoltaic (PV) systems are the most important obstacle in the spread of systems; that's why various studies are carried out on the optimization of PV systems today. Thus, PV systems can be optimized in terms of criteria such as inclination angle, PV module number, module type, module construction structure, and inverter. Different user-friendly software is used to design PV systems. Such software estimates energy production using climate data and provides economic data accordingly. However, the reliability of these data varies as the productivity of photovoltaic systems depends on climatic conditions. In this paper, it is aimed to evaluate the effectiveness of PV*SOL, PVsyst, RETScreen, and PVGIS software, widely used in the solar energy sector, under the climatic conditions of Kocaeli province. A 5,1kWp roof-top PV system installed on Kocaeli University Technology Faculty building is simulated with these programs to reveal which software is more successful in predicting real energy production data. According to comparison, $\mathrm{PV} * \mathrm{SOL}$ and $\mathrm{PV}$ syst are evaluated as the most reliable software since the yields obtained are the closest to the real energy values.
\end{abstract}

Keywords: Photovoltaic system, Simulation tool, Performance analysis, PV*SOL, PVsyst, RETScreen, PVGIS.

\section{Farklı Fotovoltaik Benzetim Yazılımlarının Karşılaştırmalı Analizi: 5,1 kWp Şebekeye Bağlı bir Fotovoltaik Sistemin Performansının Analizine İlişkin Örnek Çalışma}

$\ddot{\mathbf{O z}}$

Fotovoltaik (FV) sistemlerin kurulum maliyetlerinin yüksek olması sistemlerin yaygınlaşmasının önündeki en önemli engeldir. Bu nedenle günümüzde PV sistemlerinin eniyilenmesi konusunda çeşitli çalışmalar yapılmaktadır. FV sistemler panel eğim açısı, panel sayısı, panel tipi, panel yapısı, evirici ve akü grubu kapasitesi gibi ölçütler açısından eniyilenebilmektedir. FV sistemlerini en uygun şekilde tasarlamak için çeşitli kullanıcı dostu yazılımlar kullanılmaktadır. Bu yazılımlar, iklim verilerini kullanarak enerji üretimini tahmin eder ve buna göre ekonomik veriler sağlar. Ancak FV sistemlerin verimliliği iklim koşullarına bağlı olduğundan bu verilerin güvenilirliği değişmektedir. Bu makalede, güneş enerjisi sektöründe yaygın olarak kullanılan PV*SOL, PVsyst, RETScreen ve PVGIS yazılımlarının Kocaeli İli iklim koşullarında etkinliğinin değerlendirilmesi amaçlanmıştır. Kocaeli Üniversitesi Teknoloji Fakültesi binasına kurulan $5,1 \mathrm{kWp}$ çatı üstü PV sisteminin benzetimi gerçeğine uygun olarak bu yazılımlarla yapılarak hangi yazılımın gerçek enerji üretim verilerini tahmin etmede daha başarılı olduğu ortaya çıkarılmıştır. Karşıllaştırmaya göre PV*SOL ve PVsyst ile elde edilen sonuçlar gerçek değerlere en yakın olduğundan en güvenilir yazılımlar olarak değerlendirilmiştir.

Anahtar Kelimeler: Fotovoltaik sistem, Benzetim yazılımı, Performans analizi, PV*SOL, PVsyst, RETScreen, PVGIS.

* Corresponding Author: serkan.sezen@kocaeli.edu.tr 


\section{Introduction}

Energy is a basic part of human existence. The energy demand has been increasing for a long time due to reasons such as the increasing demand for energy, the increase in energy costs, environmental awareness, and shrinking fossil fuel reserves. The primary energy source varied over time. Fossil fuels have ruled the energy market since the nineteenth century. Overuse of fossil fuels has established major issues for example environmental change problems, the emission of greenhouse gas and the increase in pollution; also the fossil resources are decreasing day by day due to energy use, whereas renewable energy resources are the solution and are seen as important alternatives simply because environmentally friendly, reduce external dependency and provide the opportunity to use domestic energy (Y1lmaz, 2019).

Several sources of renewable energy: energy hydroelectric, geothermal energy, biomass energy, wind energy, and photovoltaic energy were been already distinguished. The main advantage of these renewable energies is that their uses do not pollute the atmosphere, and they do not produce greenhouse gases like carbon dioxide and nitrogen oxides, which are responsible for warming the earth. To handle these issues sustainable energy source use which acquired significance in recent years and with the assistance of technological and economic improvements, the change from fossil fuels to renewables has accelerated. Numerous countries have just started to invest in renewable energies instead of fossil fuels. Turkey is one of the developing countries with a population of about 80 million. It has good potential for renewable energies and a specific geographical position, that's why there is a satisfactory potential for solar, hydro, wind, and geothermal. If adequate steps are taken, Renewable energies can turn into the essential source of Turkey's energy demand, and it would have effective effects on both the economy and maintainability (Y1lmaz, 2019).

Solar energy potential is the largest energy source on Earth that needs to be used within the photovoltaic system at maximum efficiency. The increasing attention to renewable energy sources triggers the development of many types of research on efficient and stable renewable energy systems around the world. With this interest, institutions and organizations are heavily investing their resources in the development of green energy concepts. One of the most widespread uses of sustainable energy systems is photovoltaic solar cells and photovoltaic systems. Photovoltaic energy is an opportunity for efficient and sustainable development of the methods of converting this unlimited and free energy into electrical energy with photovoltaic principles is a subject that attracts the attention of scientists, this is why scientific research is developing in the direction of generalizing, improving and optimizing the use of solar systems. Its optimization is based on the criteria of sizing and maximizing the power generated to have a good yield. But, the high installation costs of photovoltaic (PV) systems are the most important obstacle in the spread of systems; that's why various studies are carried out on the optimization of PV systems today. Studies similar to the designed photovoltaic system structure were also examined in the following part.
(R. Sharma \& Goel, 2017) present an $11.2 \mathrm{kWp}$ photovoltaic system installed on the roof of the University Bhubaneswar. This PV system is on the top floor, tilted at an angle of $21^{\circ}$ of a 25 -meter height building. This project was treated between September 2014 and August 2015 where the total energy generated is $14.960 \mathrm{MWh}$. The performance parameters were studied annually like the PV inverter efficiency, module efficiency, and performance ratio which were $89.83 \%$, $13.42 \%$, and $78 \%$ respectively.

(Dey \& Subudhi, 2020) show an installed $90 \mathrm{~kW}$ gridconnected Photovoltaic system with 9 subsystems comprising 10 $\mathrm{kW}$, presenting its design, simulation, and economic evaluation. This system is located at the rooftop of Technology Rourkela University, India. The results of the simulation show that there are huge cost savings over 30 years and the total produced energy is about $15.67 \mathrm{MWh}$ in a year.

(Srivastava \& Giri, 2016) show the design of a photovoltaic system using PVsyst for the Technology University, Gorakhpur in India. In this study, detailed system output, system configuration, and system losses are calculated. From the determination of the optimal simulation size of the PV system which is $2000 \mathrm{PV}$ modules of $250 \mathrm{~W}$ and 10 grid-connected inverters of $50 \mathrm{~kW}$, we can conclude that it can supply electricity to the university. In a year, about $901.44 \mathrm{MWh}$ electricity supply to the grid, and the performance ratio is about $83.1 \%$.

(Milosavljević, Pavlović, \& Piršl, 2015) present a 2 kWp grid_connected photovoltaic system at the science faculty in Serbia for the period from January 2013 to January 2014. The inverter, the communication system, automatic meteorological stations were studied on the real climate conditions. The results show that the annual energy efficiency in 2013 decreased with the increase in ambient temperature. Also, the performance ratio was $93.6 \%$ per year and the capacity factor was $12.88 \%$ per year.

(Prasad, Reddy, Rajesh, \& Reddy, 2020) discussed the design and the simulation of a $12.4 \mathrm{kWp}$ grid connection of a photovoltaic system. This paper examines the performance ratio which is $83.2 \%$ and the energy output, it also shows the potential of a selected photovoltaic module, the various aspects like the fixing of tilt angle, the development of Sankey diagram of the power output losses, the plotting of the power and the temperature distribution of the photovoltaic system by the software PVsyst.

(Ahmed, Habeeb, Mahmood, Jalal, \& Sayed, 2019) present the modulation and the simulation of a $250 \mathrm{~kW}$ grid-connected photovoltaic system by the PVsyst. The results show that the most extreme solar irradiance at a tilt angle of $10^{\circ}$ was refined at a value of $450.8 \mathrm{MWh}$. The system also consists of 1428 solar modules of $175 \mathrm{~W}$ and ten SMA $25 \mathrm{~kW}$ inverters. Due to the strategic position of Baghdad, this study shows that Baghdad has incredible potential for solar energy utilization.

(S. Sharma, Kurian, \& Paragond, 2018) present the design of the solar photovoltaic system of an academic institution through PVsyst. This study includes the theoretical analysis to accomplish maximum power, efficiency, and performance ratio on different conditions by PVsyst. It also analyzes the performance of the system, which is found to be very acceptable at a load of $54 \mathrm{~kW}$. This paper compares various orientations of the panels for the same building; the result shows that the 
specific product is at its high level with satisfactory effectiveness when the system has zero azimuth angles.

(K. A. Kumar, Sundareswaran, \& Venkateswaran, 2014) discusses a study of a $20 \mathrm{kWp}$ solar plant on the roof of the manufacturing industry in India. This project highlights a few salient characteristics of the grid-connected solar photovoltaic, operational performance, and economic calculations. This paper additionally describes the setting up of the total photovoltaic system which incorporates the inverter unit, the PV array, the MPP tracking system; and the computer control of the system, and it extends its discussion about themaintenance of the PV modules.

(Dondariya et al., 2018) presents in this study the use of different simulation software, PV*SOL, SISIFO, SolarGIS, and PVGIS to analyze the performance of $6,4 \mathrm{kWp}$ gridconnected PV system constituted of MonoCrystalline modules on the rooftop capable of supplying electricity. The annual energy yield is $1528,12 \mathrm{kWh} / \mathrm{kWp}$. That's means that the grid-connected system installation is a good indicator in the central region of India. The energy generated feed into the grid is about $85,30 \%$ per year, and the performance ratio is reasonably good refers to $75,01 \%$.

(Barua, Prasath, \& Boruah, 2017) present the design and the feasibility study of a solar photovoltaic system of the academic campus. The analyses of the simulation results from PVsyst indicate that the project yields energy is about $11 \%$ of total annual energy which is $590 \mathrm{MWh}$ annually consumed. The process of electricity generation from a solar photovoltaic system could save 42 tonnes of carbon dioxide.

PV systems can be optimized in terms of criteria such as inclination angle, PV module number, module type, module construction structure, inverter, battery group capacity. Various user-friendly software is used to design PV systems in the most appropriate way. Such software estimates energy production using climate data and provides economic data accordingly. However, the reliability of these data varies as the productivity of photovoltaic systems depends on climatic conditions. This study aims to evaluate the effectiveness of PV*SOL, PVsyst, RETScreen, and PVGIS software, which are widely used in the solar energy sector, and reveal which software is more successful in predicting real energy production data under the climatic conditions of Kocaeli province.

The remainder of this paper is organized as follows: section 2 introduces the general features of the software, section 3 describes PV system features, section 4 describes the methodology of the PV system performance analysis, section 5 presents simulation results and section 6 compares simulation data with real data.

\section{Photovoltaic System Software}

In this part, a comparative analysis of the main options of 4 simulation software developed for photovoltaic system design will be discussed.

\subsection{Presentation of $\mathrm{PV} * \mathrm{SOL}$}

PV*SOL is that the leading software employed by engineers, planners, architects, installers, and good technicians around the world to set up and style efficient PV systems. With PV*SOL premium, it will be attainable to position and estimate $3 \mathrm{D}$ objects to accurately verify the results on the photovoltaic performance of shading from nearby objects. With $\mathrm{PV} * \mathrm{SOL}$, all kinds of modern PV systems from small rooftop systems with a few modules to medium-sized systems on commercial roofs to large solar parks with up to 100,000 modules can be designed and simulated (PV*SOL software, 2021).

\subsection{Presentation of PVGIS}

Photovoltaic Geographical Information System (PVGIS) Provides internet access to temperature information and solar radiation and PV performance evaluation tools for any location in Africa and Europe, as well as much of Asia. After defining the module's tilt and orientation, this software calculates the yearly and monthly potential electricity of a Photovoltaic system. After selecting the menu grid-connected, we can access a calculator for fixed solar panels as well as free in excel and pdf downloads of all the results of simulations. PVGIS application is a free solar PV energy calculator enforced by the Research Center in Science services and it is available online in different languages such as French, Italian English, German and Spanish (PVGIS web page, 2021).

\subsection{Presentation of PVsyst}

PVsyst is a PV system simulation program developed by the University of Geneva, Switzerland, which helps in making and examining the results of photovoltaic system designs such as grid-connected or off-grid PV systems, PV irrigation systems, and DC grids. This program allows more detailed calculations and the use of different parameters compared to similar ones. Also, this program is so easy to access to the database which contains the properties of photovoltaic system components such as PV panels and inverters. PVsyst is software designed for use by planners, engineers, specialists, researchers, and architects, but also a very helpful instructive tool. It includes in-depth contextual help, which clarifies in detail the system and models used and offers a cost-effective approach with the direction in the development of a project. PVsyst can import climate data from a dozen various sources as well as personal data. PVsyst offers 3 levels of study of the PV system, which corresponds roughly to the different stages of the project (PVsyst 6.8.3 software, 2021).

\subsection{Presentation of RETScreen}

RETScreen is a complex mathematical model for assessing energy production, financial viability, cost savings, emission reductions, and risks for different types of energy and clean technologies. In the Expert version of RETScreen, the software capabilities have been extended for renewables, cogeneration, and energy grids to a full range of heating and cooling technologies and economically viable energy efficiency measures. The International interest in this software has been increased by the expansion of climate data needed by the tool, in order to cover the entire surface of the planet, including regions connected to a central electricity network, isolated and off-grid, as well as by translating the software into 36 languages, thus covering approximately two-thirds of the world's population (RETScreen Expert software, 2021). 
Table 1. Main characteristic of the softwares

\begin{tabular}{|c|c|c|c|c|}
\hline Software & $\begin{array}{c}\text { Developed by / } \\
\text { availability }\end{array}$ & Analysis & Advantages & Disadvantages \\
\hline PVsyst & $\begin{array}{l}\text { Developed by the } \\
\text { environmental sciences } \\
\text { institution, University of } \\
\text { Geneva, Switzerland. }\end{array}$ & $\begin{array}{l}\text { Financial } \\
\text { estimation used } \\
\text { for both on-grid } \\
\text { and off-grid. } \\
\text { Performance } \\
\text { analysis; }\end{array}$ & $\begin{array}{l}\text { - Identify weaknesses in the } \\
\text { design of the system using the } \\
\text {-loss diagram. } \\
\text { - Large databases of elements } \\
\text { of meteorological and } \\
\text { photovoltaic systems; }\end{array}$ & $\begin{array}{l}\text {-Inability to manage } \\
\text { shadow analysis. } \\
\text { - There is no single line } \\
\text { diagram, } \\
\text { - The screen of software } \\
\text { cannot be enlarged to allow } \\
\text { the user to review all } \\
\text { parameters while using the } \\
\text { monitor, }\end{array}$ \\
\hline$P V^{*} S O L$ & $\begin{array}{l}\text { Developed by Valentine } \\
\text { Energy Software, } \\
\text { Germany } \\
\text { PV*SOL released in } \\
\text { March } 2018 .\end{array}$ & $\begin{array}{l}\text { 3D visualization } \\
\text { and shading } \\
\text { analysis; } \\
\text { Supply the } \\
\text { performance } \\
\text { analysis; } \\
\text { Provides the } \\
\text { economic } \\
\text { analysis }\end{array}$ & $\begin{array}{l}\text {-Huge meteorological database } \\
\text { with more than } 8,000 \text { climatic } \\
\text { locations around the world. } \\
\text {-Robust module database of } \\
\text { more than } 21000 \text { and inverter } \\
\text { database with } 5100 \text { inverters. } \\
\text {-Manual addition of custom } \\
\text { modules and inverters. }\end{array}$ & $\begin{array}{l}\text {-Complexity of modeling in } \\
\text { buildings and sites. } \\
\text {-There is an error in the } \\
\text { presentation of the } \\
\text { electrical diagram. } \\
\text {-The advanced scientific } \\
\text { computing is not supported. }\end{array}$ \\
\hline Retscreen & $\begin{array}{l}\text { Developed by Natural } \\
\text { Resources Canada }\end{array}$ & $\begin{array}{l}\text { Feasibility, } \\
\text { Performance, } \\
\text { Benchmark } \\
\text { Portfolio } \\
\text { analysis }\end{array}$ & $\begin{array}{c}\text {-Contains a strong } \\
\text { meteorological and material } \\
\text { database. } \\
\text {-Comprehensive integrated } \\
\text { training material. } \\
\text {-Solid financial analysis }\end{array}$ & $\begin{array}{l}\text {-When using free view } \\
\text { mode version, it's } \\
\text { impossible to save, print } \\
\text { and export files and no } \\
\text { option for sharing data. } \\
\text {-Does not support advanced } \\
\text { calculations. }\end{array}$ \\
\hline PVGIS & $\begin{array}{c}\text { Developed by the } \\
\text { European Commission } \\
\text { and the National } \\
\text { Renewable Energy } \\
\text { Laboratory } \\
\text { (UnitedStates) }\end{array}$ & $\begin{array}{l}\text {-Offers the } \\
\text { values of } \\
\text { atmospheric } \\
\text { conditions } \\
\text { monthly, the } \\
\text { total irradiance, }\end{array}$ & $\begin{array}{l}\text {-A free source search tool. } \\
\text {-Provides PV technology to } \\
\text { geographic regions. } \\
\text {-It is a policy support system } \\
\text { within the European } \\
\text { Commission. }\end{array}$ & $\begin{array}{l}\text {-There are a monthly solar } \\
\text { irradiation estimates just } \\
\text { until } 2016 \text {. }\end{array}$ \\
\hline
\end{tabular}

\section{Description of the Grid-Connected PV System}

Solar energy systems are divided into two types depending on the connection to the grid. Grid-connected systems carry produced electricity to the grid during the day. In cases where there is no possibility of benefiting from the sun (eg in the evening hours), the electrical energy needed is obtained from the grid. In these systems, the direct current of the panels is converted to alternating current using inverters. In systems installed in homes or industrial systems, the necessary energy is used, and the excess is transferred to the interconnected system with the same frequency and voltage as the grid by the decoupling system. In power plant installations, energy is transmitted directly to the grid.

Within the scope of this article, the real energy production data of the $5.1 \mathrm{kWp}$ PV system installed on the roof of Kocaeli University Umuttepe Campus Technology Faculty building and commissioned in July 2014. Figure 1 shows a photo of the building taken from the Google Earth program. Kocaeli University Campus is geographically located in the city of Kocaeli, which is located in the Marmara region of Turkey. The PV system was established by the Energy Systems Engineering Department of our University's Faculty of Technology within the scope of the TUBITAK project numbered 113E143 carried out between 2013 and 2016. The PV system is grid-connected and continues to produce energy. The energy production data of the PV system are monitored online via the Ethernet output inverter in the system and recorded in the web environment. The technical information of the PV modules used is given in Table 2. The PV power system installed on the roof of Kocaeli University Faculty of Technology building, seen in Figure 3, consists of 2 strings; each string contains 10 solar panels connected in series. Symo 4,5-3-S model of Fronius International company, whose properties are given in Table 3, is used as an inverter in the system.

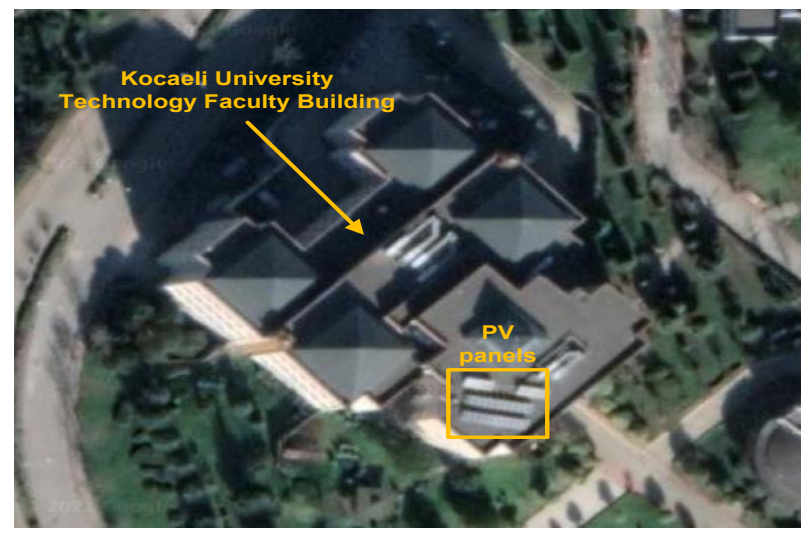

Figure 1. Photo of the location of the PV system taken from Google Earth 


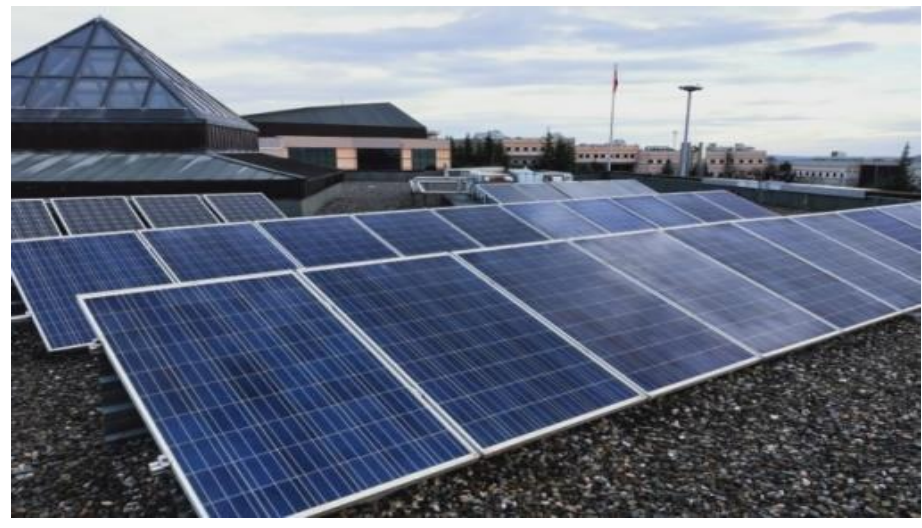

Figure 2. The PV panels on Kocaeli University Technology Faculty building

Table 2. Description of the PV panels

\begin{tabular}{|l|c|}
\hline Manufacturer / Model & Yingli / YL255P - 29b \\
\hline Technology & Si-poly \\
\hline Rated voltage & $30.6 \mathrm{~V}$ \\
\hline Rated current & $8.32 \mathrm{~A}$ \\
\hline Max series fuse & $15 \mathrm{~A}$ \\
\hline Open circuit voltage & $38.7 \mathrm{~V}$ \\
\hline Short circuit current & $8.88 \mathrm{~A}$ \\
\hline
\end{tabular}

Table 3. Description of the inverter

\begin{tabular}{|l|c|}
\hline The inverter & Symo 4 .5-3 S \\
\hline Minimum MPP Voltage & $150 \mathrm{~V}$ \\
\hline Minimum voltage for & $300 \mathrm{~V}$ \\
\hline Maximum input Current & $15,3 \mathrm{~A}$ \\
\hline Nominal MPP voltage & $610 \mathrm{~V}$ \\
\hline Maximum MPP voltage & $800 \mathrm{~V}$ \\
\hline Absolute Max PV voltage & $1000 \mathrm{~V}$ \\
\hline Output side (AC) & 3 phases \\
\hline Output frequency & $50-60 \mathrm{~Hz}$ \\
\hline Nominal PV power & $4,59 \mathrm{~kW}$ \\
\hline Maximum PV current & $24 \mathrm{~A}$ \\
\hline Nominal AC current & $6,5 \mathrm{~A}$ \\
\hline Maximum efficiency & $98 \%$ \\
\hline
\end{tabular}

In the experimental system, Yingli YGE-255P-29b type solar panels are used. There are two strings of PV panels and each string is formed by 10 panels in series. The Polycrystalline PV panels are shown in the Figure 2.

\section{Methodology of the PV System for Performance Analysis}

\subsection{Simulation of Photovoltaic System with PV*SOL}

Although PV system design in PVSOL depends on the system type, it is generally carried out in 6 stages: "Project Data", "System Type, Climate, and Grid", "3D Design", "Cables", "Financial Analysis" and "Results". In the Project Data section, some identity information about the project such as project number, project designer, and customer information is entered. In the System Type, Climate and Grid section, the type of PV system (on the grid, off-grid, etc.) is determined, the installation location is selected, and network-related definitions are made. In the 3D Design section, many predefined building types and shading objects such as trees or chimneys are available as modeling aids. Own buildings can be created or imported. Figure 3 shows campus building objects in $\mathrm{PV} * \mathrm{SOL}$.

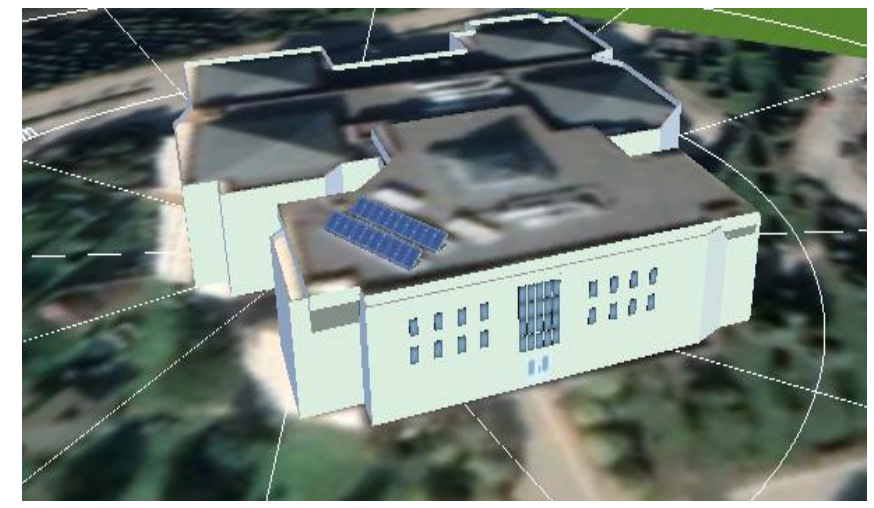

Figure 3. 3D Building object in $\mathrm{PV} * \mathrm{SOL}$ extruded from Google Earth

Table 4 shows $\mathrm{PV} * \mathrm{SOL}$ simulation results in terms of system performance, annual production forecast, performance report, etc. According to simulation results, the PV system can provide $6,306 \mathrm{kWh}$ per year. This production is based on the solar radiation of a given month. According to the results, the maximum production takes place in July and June as shown in Figure 4.

Table 4. $P V^{*} S O L$ Simulation results

\begin{tabular}{|l|c|}
\hline PV generator output & $5,1 \mathrm{kWp}$ \\
\hline Spec. annual yield & $1236,55 \mathrm{kWh} / \mathrm{kWp}$ \\
\hline Performance ratio $(P R)$ & $83,7 \%$ \\
\hline Yield reduction due to shading & $3,4 \% /$ year \\
\hline Grid Feed-in & $6306 \mathrm{kWh} /$ year \\
\hline $\begin{array}{l}\text { Grid feed-in in the first year (incl. } \\
\text { module degradation) }\end{array}$ & $6283 \mathrm{kWh} /$ year \\
\hline Standby consumption (Inverter) & $14 \mathrm{kWh} /$ year \\
\hline $\mathrm{CO}_{2}$ emissions avoided & $2964 \mathrm{~kg} /$ year \\
\hline
\end{tabular}

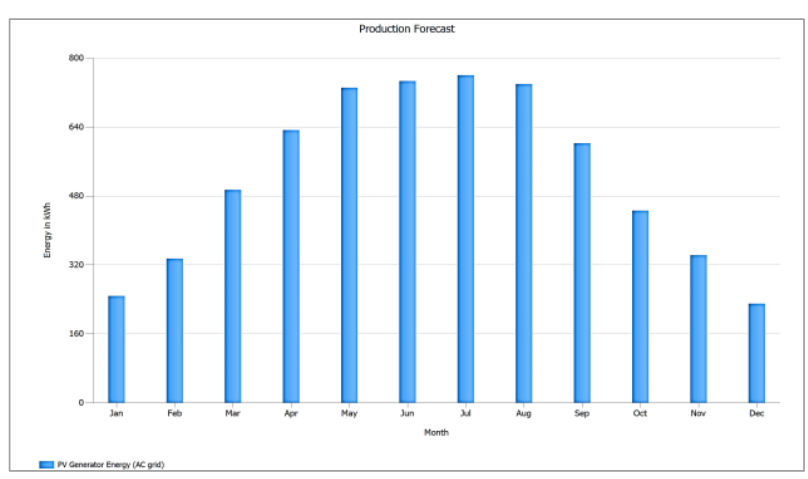

Figure 4. PV*SOL Energy production forecast 
Table 5. Monthly PV generator energy in $P V^{*} S O L$

\begin{tabular}{|l|c|}
\hline Month & $\begin{array}{c}\text { PV Generator Energy } \\
\text { (AC grid, kWh) }\end{array}$ \\
\hline Jan & 247,5 \\
\hline Feb & 334,6 \\
\hline Mar & 494,2 \\
\hline Apr & 632,5 \\
\hline May & 730,9 \\
\hline Jun & 746,2 \\
\hline Jul & 760 \\
\hline Aug & 739,7 \\
\hline Sep & 602,4 \\
\hline Oct & 445,9 \\
\hline Nov & 342,7 \\
\hline Dec & 229,9 \\
\hline Total & 6306,5 \\
\hline
\end{tabular}

Monthly PV generation energy in $\mathrm{PV} * \mathrm{SOL}$ is illustrated in Table 5.

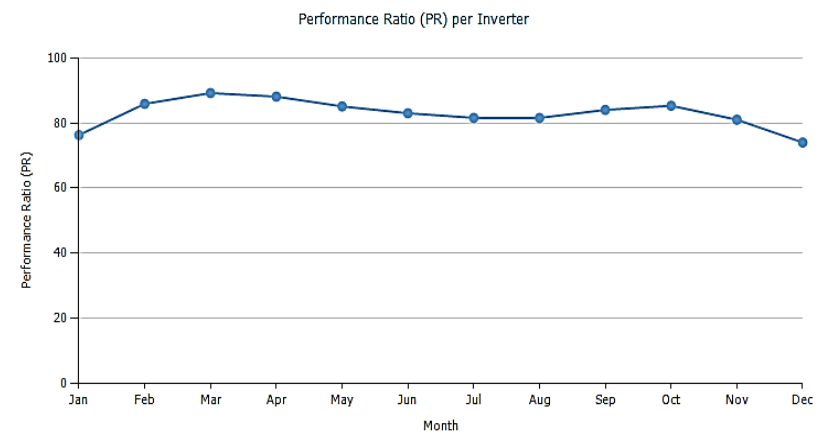



Figure 5. Performance ratio per inverter in $\mathrm{PV} * \mathrm{SOL}$

Table 6. Monthly performance ratio in $P V^{*} S O L$

\begin{tabular}{|l|c|}
\hline Month & Performance Ratio Inverter \% \\
\hline Jan & 76,32 \\
\hline Feb & 85,92 \\
\hline Mar & 89,24 \\
\hline Apr & 88,15 \\
\hline May & 85,14 \\
\hline Jun & 83,03 \\
\hline Jul & 81,62 \\
\hline Aug & 81,6 \\
\hline Sep & 84,05 \\
\hline Oct & 85,34 \\
\hline Nov & 81,05 \\
\hline Dec & 74,04 \\
\hline
\end{tabular}

The performance ratio is a measure of the specific power of the system relative to its rated capacity. For this PV system, the annual performance ratio as shown in Figure 5, is 83,7\%. On the other hand, the performance ratio of the inverter, illustrated in Table 6, is high over the months of March and April which are respectively $89.24 \%$ and $88.15 \%$. Conversely, the minimum performance ratio that came out in January and December, which are $76,32 \%$ and $74,04 \%$ respectively. These results show the direct relationship between weather conditions and system performance. In addition, it is observed that the high air temperatures in the summer months affect the performance ratio negatively.

\subsection{Simulation of Photovoltaic System with PVGIS}

PVGIS is an online software used to calculate the various parameters of a solar photovoltaic system. To perform the simulation, it is sufficient to enter the radiation databases and choose the PV technology to be used, it is also necessary to enter the system capacity required for the installation and specify the total allowable losses of the system. After that, the mounting pattern, azimuth, and tilt angle and tracking options have been chosen and a report is generated, which includes data on daily irradiation, average daily and monthly electricity production, average monthly total irradiation per square meter received by the modules, and total losses of the photovoltaic system. In order to choose the tilt angle which was determined around $30^{\circ}$ and the azimuth value was $12^{\circ}$ by the rule part of the Google Earth Pro program since the programs used in the study are referenced to the South. The provided input data is shown in Table 7.

Table 7. The provided PVGIS inputs

\begin{tabular}{|l|c|}
\hline Location (lat/lon) & $40.810 / 29.927$ \\
\hline Horizon & Calculated \\
\hline Database used & PVGIS - SARAH \\
\hline PV technology & Crystalline silicon \\
\hline PV installed $(\mathrm{kwp})$ & 5.1 \\
\hline System loss & $14 \%$ \\
\hline
\end{tabular}

Table 8. PVGIS simulation results

\begin{tabular}{|l|c|}
\hline Slope angle & $31(\mathrm{opt})$ \\
\hline Azimuth angle & $-3(\mathrm{opt})$ \\
\hline $\begin{array}{l}\text { Yearly PV energy } \\
\text { production }\end{array}$ & $6239,09 \mathrm{kWh}$ \\
\hline Yearly in plane irradiation & $1626,01 \mathrm{kWh} / \mathrm{m}^{2}$ \\
\hline Year to year variability & $260,94 \mathrm{kWh}$ \\
\hline Angle of incidence & $-2,62 \%$ \\
\hline Spectral effects & $0,88 \%$ \\
\hline $\begin{array}{l}\text { Temperature and low } \\
\text { irradiance }\end{array}$ & $-10,94 \%$ \\
\hline Total loss & $-24,76 \%$ \\
\hline
\end{tabular}




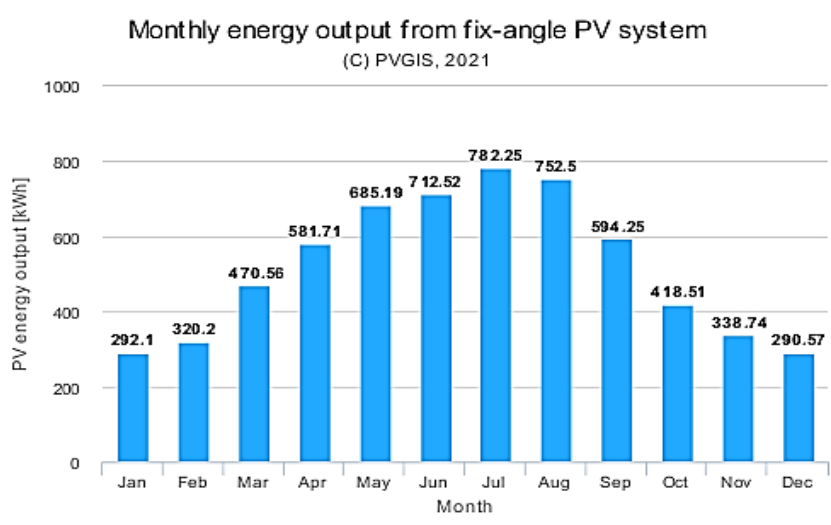

Figure 6. Monthly electricity production graph in PVGIS

Table 9. Monthly electricity production in PVGIS

\begin{tabular}{|l|c|}
\hline Month & $\begin{array}{c}\text { Electricity } \\
\text { production }(\mathbf{k W h})\end{array}$ \\
\hline January & 292,1 \\
\hline February & 320,2 \\
\hline March & 470,6 \\
\hline April & 581,7 \\
\hline May & 685,2 \\
\hline June & 712,5 \\
\hline July & 782,3 \\
\hline August & 752,5 \\
\hline September & 594 \\
\hline October & 418,5 \\
\hline November & 338,7 \\
\hline December & 290,6 \\
\hline Total & 6238,9 \\
\hline
\end{tabular}

Monthly electricity production is shown in Table 9. In July and August, the level of production is high.

\subsection{Simulation of Photovoltaic System with PVsyst}

The simulation system of a grid-connected photovoltaic is technically analyzed using software tool PVsyst; this simulated system includes PV modules, inverters, and a grid network interface. The results of the simulation of the PV system from the simulation model of a $5,1 \mathrm{kWp}$ PV system are analyzed. Specific production, mainly the energy production, the performance ratio, and the deflection losses are achieved. The steps of the simulation procedure adopted for the analysis are as follows:

- Within the design menu, we specified the geographic area and meteorological information of the current site.

- The PVsyst database which is composed of the orientation of the photovoltaic modules, their type, and the type of inverter, is used to design the PV system accordingly.

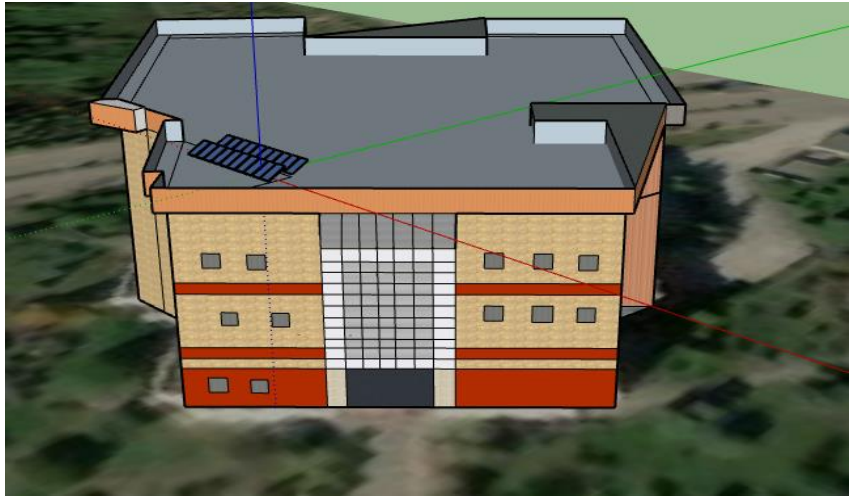

Figure 7. The design of Technology Faculty building designed with Sketchup

With the help of Sketchup, this building is designed approximately in Figure 7, after that is exported to PVsyst.

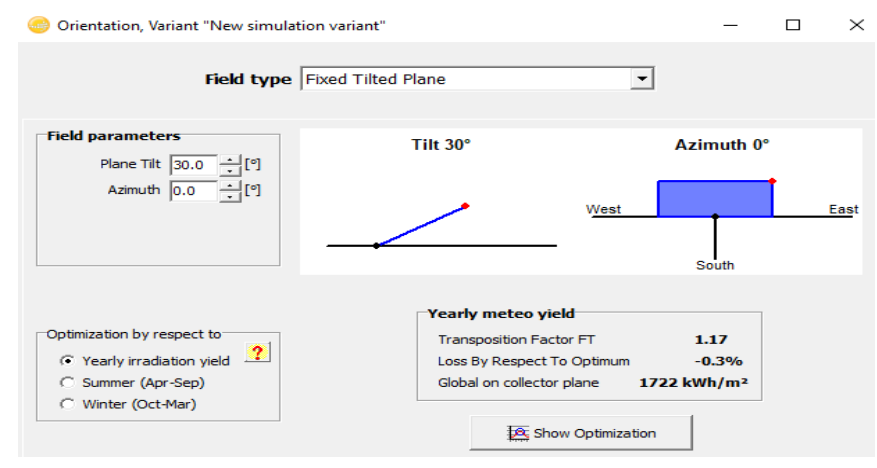

Figure 8. Determination of the orientation and the Azimuth in PVsyst

The performance curve of Tilt angle and plane orientation is shown in Figure 8.

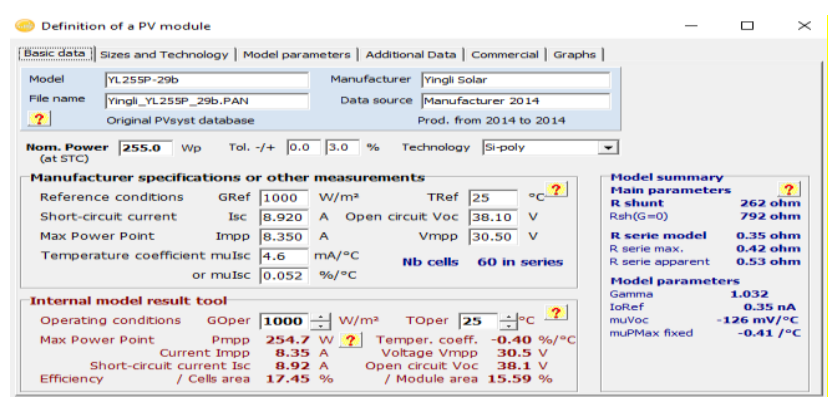

Figure 9. Definition of PV module in PVsyst

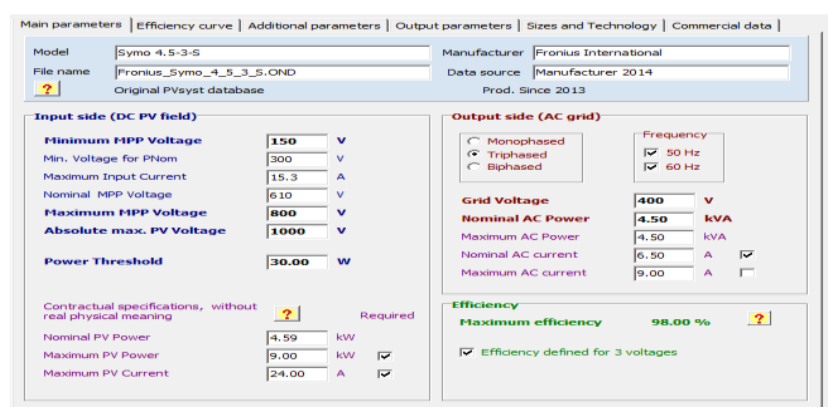

Figure 10. Definition of the inverter in PVsyst

The PV module and inverter characteristics are identified in Figure 9 and Figure 10 respectively. 
Table 10. PVsyst main simulation results

\begin{tabular}{|l|c|c|c|c|}
\hline & $\begin{array}{c}\text { GlobHor } \\
\mathbf{M W h} / \mathbf{m}^{2}\end{array}$ & $\begin{array}{c}\text { GlobInc } \\
\mathbf{M W h} / \mathbf{m}^{2}\end{array}$ & $\begin{array}{c}\mathbf{E} \text { _Grid } \\
\mathbf{M W h}\end{array}$ & $\mathbf{P R}$ \\
\hline January & 43,1 & 63,7 & 0,283 & 0,873 \\
\hline February & 54,4 & 70,1 & 0,315 & 0,88 \\
\hline March & 89,3 & 103,3 & 0,451 & 0,856 \\
\hline April & 127,4 & 134,5 & 0,58 & 0,845 \\
\hline May & 162,8 & 160 & 0,666 & 0,816 \\
\hline June & 176,3 & 165,7 & 0,678 & 0,802 \\
\hline July & 181,4 & 174,6 & 0,705 & 0,792 \\
\hline August & 159,1 & 165,7 & 0,671 & 0,793 \\
\hline September & 118 & 134,4 & 0,559 & 0,815 \\
\hline October & 80,3 & 105,1 & 0,445 & 0,83 \\
\hline November & 56,2 & 84,5 & 0,37 & 0,859 \\
\hline December & 42,4 & 62,8 & 0,281 & 0,878 \\
\hline Year & 1290,6 & 1424,3 & 6,003 & 0,826 \\
\hline
\end{tabular}

GlobHor: the global irradiance on the horizontal plane

GlobInc: the global incident energy on the collector plane without optical corrections,

E_Grid: the energy injected into the grid considering the losses within the electrical components

PR: the performance ratio

In Table 10, all the main results and all the calculated results for each variable mentioned in the balances in the form of annual and monthly values are carried out. The table includes all variables such as the global irradiance on the horizontal plane and on the collector plane without optical corrections, the effective global soiling losses and shading losses, the direct energy, the energy injected into the grid performance ratio.

For this study, the obtained annual global irradiance is 1290 , $6 \mathrm{kWh} / \mathrm{m}^{2}$, the annual global incident energy is $1424,3 \mathrm{kWh} / \mathrm{m}^{2}$, and the effective global irradiance is $1344,5 \mathrm{kWh} / \mathrm{m}^{2}$. The annual DC energy with this effective irradiance is $6274 \mathrm{kWh}$ and the total annual amount of energy produced from the $5,1 \mathrm{kWp}$ or referred to as produced energy is $6003 \mathrm{kWh} / \mathrm{year}$, the annual specific production installed is $1177 \mathrm{kWh} / \mathrm{kWp} / \mathrm{year}$. And for the simulated study for Kocaeli province, the performance ratio PV system is approximately $82.6 \%$.

During the month of July, the highest amount of energy from the photovoltaic plant generated and injected into the network is $705 \mathrm{kWh}$ and the lowest amount of $\mathrm{AC}$ power fed into the grid is $281 \mathrm{kWh}$ in December.

The energy of the photovoltaic generator is a direct current converted into alternating energy to supply the network. This energy generated by the photovoltaic generator is not identical to the energy injected into the network. Therefore, during this time, a certain amount of power is wasted in terms of the loss of AC wiring.

The standardized productions are presented in Figure 11 such as system losses; collection losses and useful energy produced per $\mathrm{kWp}$ installed / day were evaluated to represent the PV system performance. Lc which corresponds to the collection losses or capture losses of the PV generator is approximately $0.53 \mathrm{kWh} / \mathrm{kWp}$ /day. Ls is the loss of the system which is 0.15 $\mathrm{kWh} / \mathrm{kWp} /$ day and $\mathrm{Yf}$ is the generated useful energy of 3.22
kWh/kWp/day (N. M. Kumar, Kumar, Rejoice, \& Mathew, 2017).

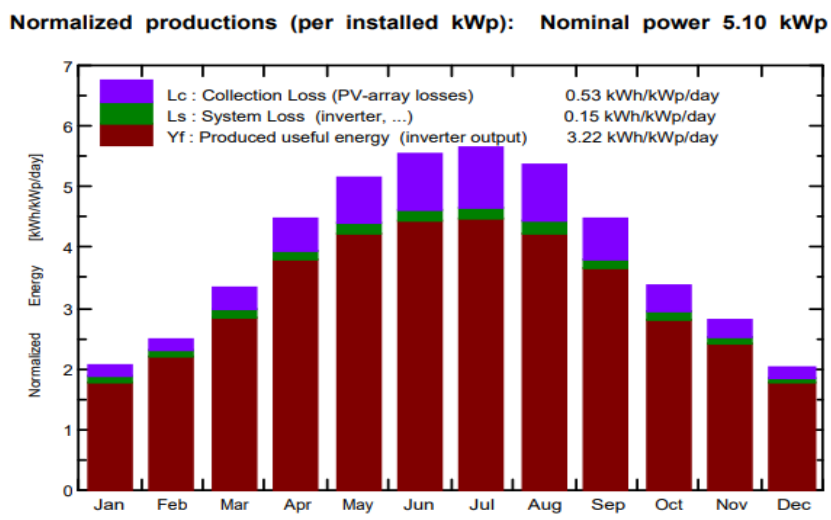

Figure 11. PVsyst normalized energy productions in PVsyst

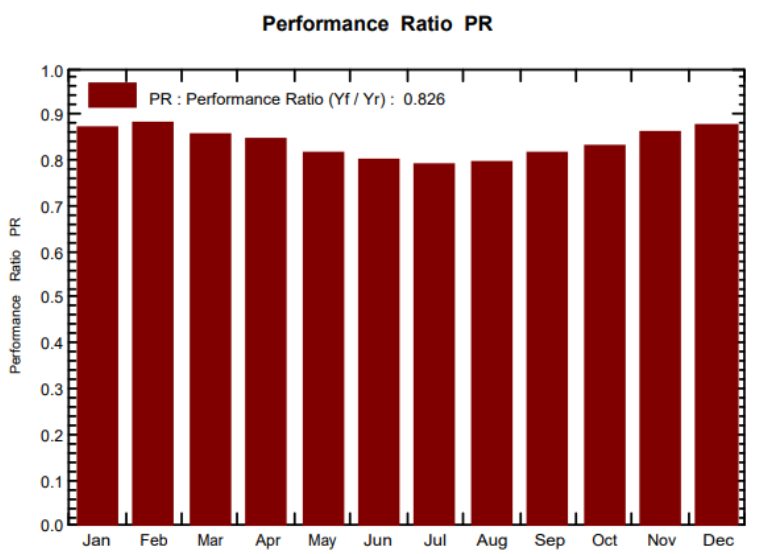

Figure 12. Performance ratio in PVsyst

The performance ratio or in other words the annual average value intended for the Si-poly photovoltaic system of $5.1 \mathrm{kWp}$ is $82.6 \%$. There is a small variation in the performance ratio on a monthly basis, especially during the summer months, in Figure 12; there is a slight decrease in May, June, July, August.

From the simulation by PVsyst, the loss diagram in Figure 13 has been obtained; this diagram makes it possible to analyze the various losses encountered during the installation of the photovoltaic installation, and details of different losses in the system are present below:

This diagram represents in the first part the global horizontal radiation, which is a combination of global diffuse radiation and global direct radiation calculated every hour over a year for a horizontal surface. For our PV system, it is $10.4 \%$.

- The actual radiation reaching the modulus is $0,08 \%$.

- The loss of radiation because of the direct shading effects is $0.92 \%$.

- Overall AMI Factor: The higher angle of incidence which depends on the position of the sun causes the greater loss. It's around 2, 97\%.

- Due to the level of irradiance, the energy loss in our system is $0.92 \%$.

- The global radiance on the horizontal plane is $1291 \mathrm{kWh} / \mathrm{m}^{2}$

- The effective radiation on the collectors refers to the radiation after the losses described earlier, multiplied by the PV area of the module surface as defined in the PAN file which is the case for our $32 \mathrm{~m}^{2} \mathrm{PV}$ system. The value is therefore 1345 
$\mathrm{kWh} / \mathrm{m}^{2}$.

- The nominal generator energy under standard test conditions is $6.86 \mathrm{MWh}$ after PV conversion.

- The annual virtual array energy of the system at the MPP is 6.28 MWh.

- The nominal panel energy at STC efficiency: PV conversion performance multiplied by the effective radiation on the collectors is $15.7 \%$.

In the second part, we list all kinds of losses in the PV system like PV loss due to irradiation, which is $0.92 \%$.

- The PV loss due to temperature variations refers to 5, 22\% which causes the reduction in module performance.

- The loss of energy due to the electrical effect of shading, such as in a system with strings connected in parallel refers to $1.3 \%$.

- The quality loss of the module is $0.75 \%$.

- Mismatch loss in modules is the energy loss refers to $1.1 \%$ in the system.

- Ohmic wiring loss is $0.87 \%$.

- The inverter loss during operation, or efficiency, which is the DC to AC conversion efficiency of the inverter, weighted by the change in power stages during the year, refers to $4.3 \%$ for our system (PVsyst Application Note, 2021).

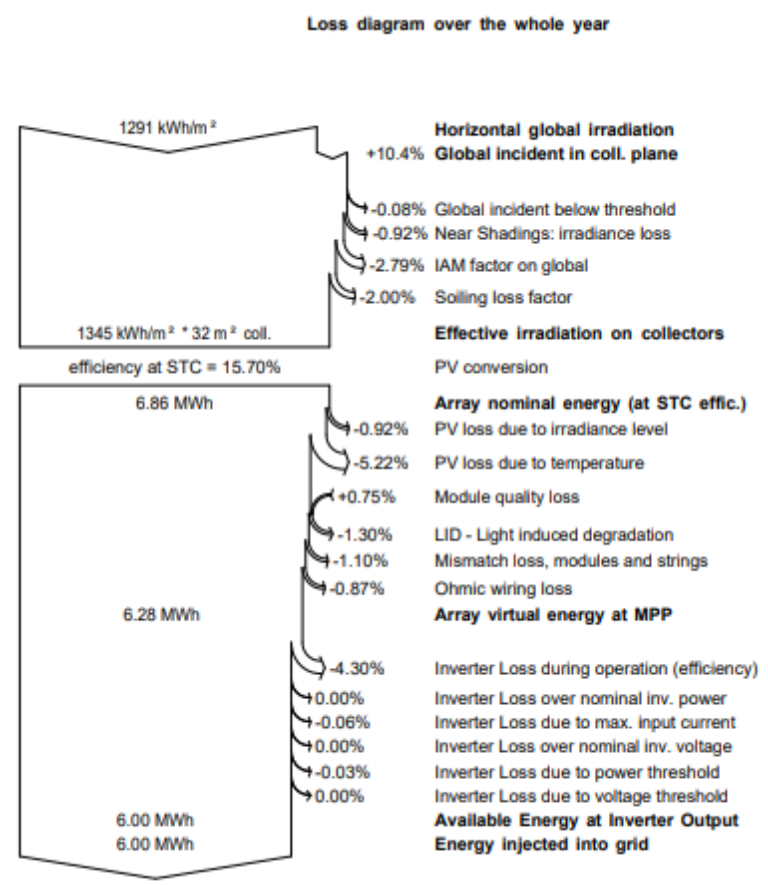

Figure 13. Loss diagram over the whole year in PVsyst

\subsection{Simulation of Photovoltaic System with RETScreen}

The complete meteorological details of the region closest to the place of analysis are given by Retscreen software in Figure 14. The data also regarding daily solar radiation, earth temperature, wind speed, etc are provided. The data displayed is provided by NASA.

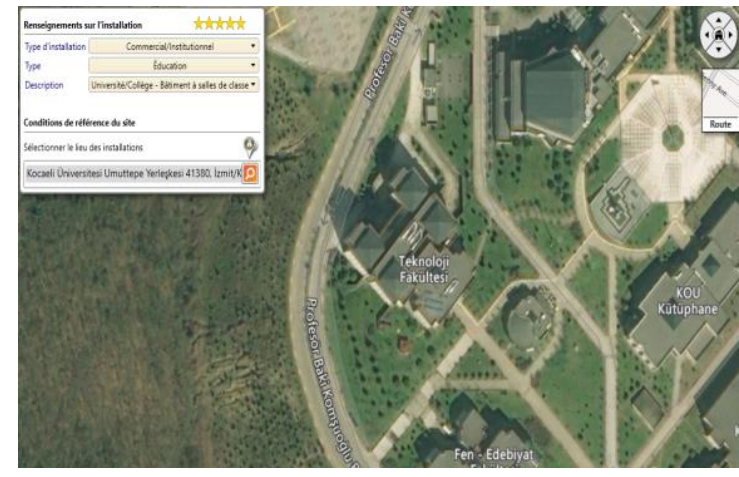

Figure 14. The location photo taken from RETScreen
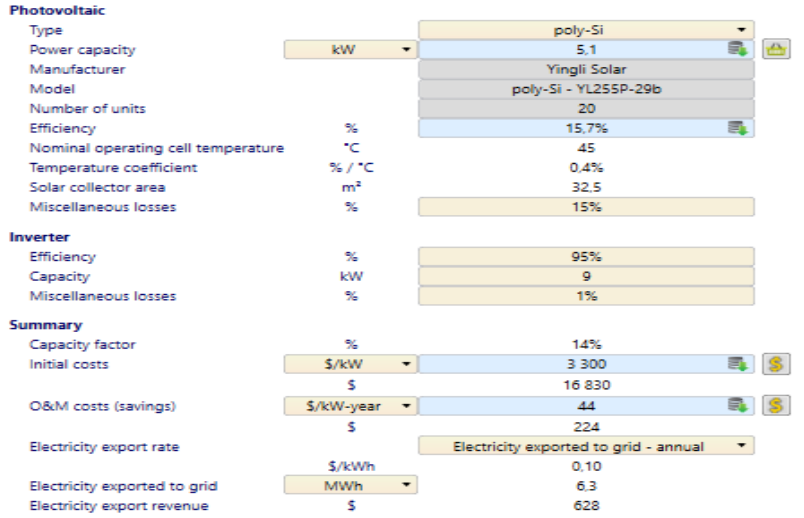

Figure 15. PV system parameters defined by RETScreen

The parameters of the PV system are defined by Retscreen as shown in Figure 15.

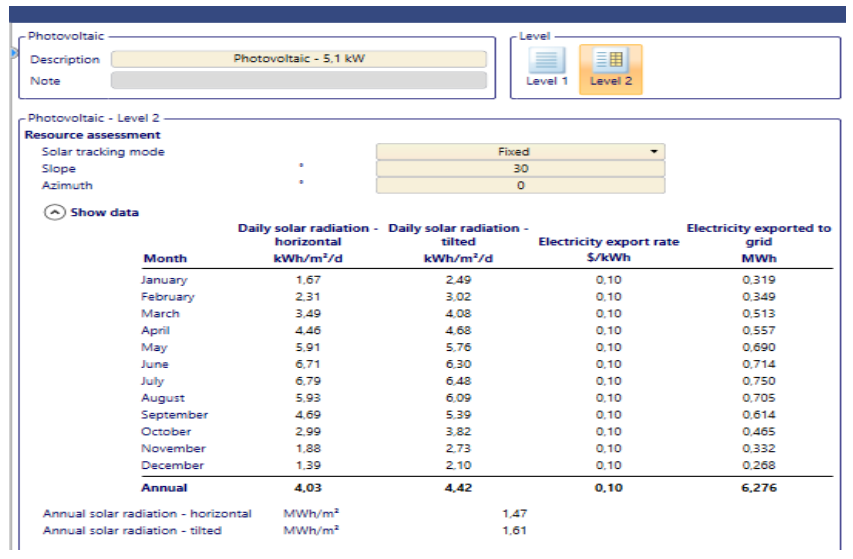

Figure 16. The electricity exported to the grid

The values of the field as per the convenience of the user are given in the energy model in RETScreen as shown in Figure 16.

In this study, the following conclusions regarding the simulated output of a $5.1 \mathrm{kWp}$ photovoltaic system using the simulation tool Retscreen were illustrated in Figure 17.

- The electricity exported to the grid is $6276 \mathrm{MWh} /$ year.

- The maximum energy exported to the grid is $750 \mathrm{kWh}$ in July, and the least energy in December is $268 \mathrm{kWh}$.

- In the simulated study for Kocaeli province, the efficiency of the inverter is approximately $95 \%$. 


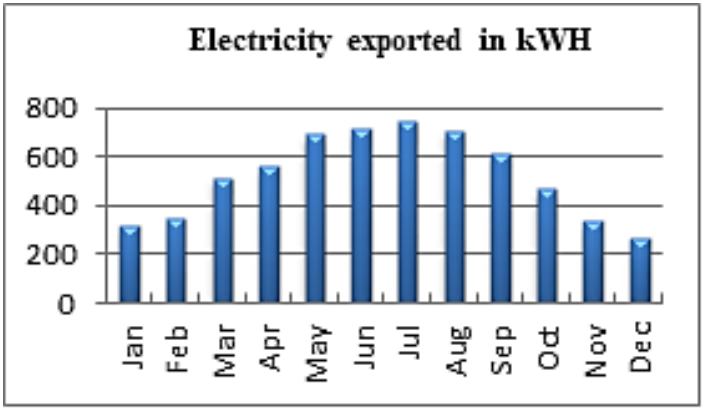

Figure 17. The exported electricity in RETScreen

\section{Real Energy Production Data of PV System}

The real energy production data of the PV system is monitored via Fronius solar web portal. The Fronius Solar Web is a free, online portal with which we can easily and conveniently monitor PV plants and can provide an overview of all current and archive data for the PV plant(Fronius solar web portal). The results of our photovoltaic system illustrated in Table 11 are monitored by Fronius solar web. The most energy injected into the grid is $872,96 \mathrm{kWh}$ in July and the least energy in January with $125,54 \mathrm{Kwh}$. And the total energy provided annually is $6436,54 \mathrm{kWh}$.

Table 11. Real energy production data

\begin{tabular}{|l|c|}
\hline Month & Energy in kWh \\
\hline Jan & 125,54 \\
\hline Feb & 357,71 \\
\hline Mar & 499,38 \\
\hline Apr & 782,29 \\
\hline May & 701,37 \\
\hline Jun & 764,01 \\
\hline Jul & 872,96 \\
\hline Aug & 767,53 \\
\hline Sep & 597,26 \\
\hline Oct & 459,3 \\
\hline Nov & 369,07 \\
\hline Dec & 140,12 \\
\hline Total & 6436,54 \\
\hline
\end{tabular}

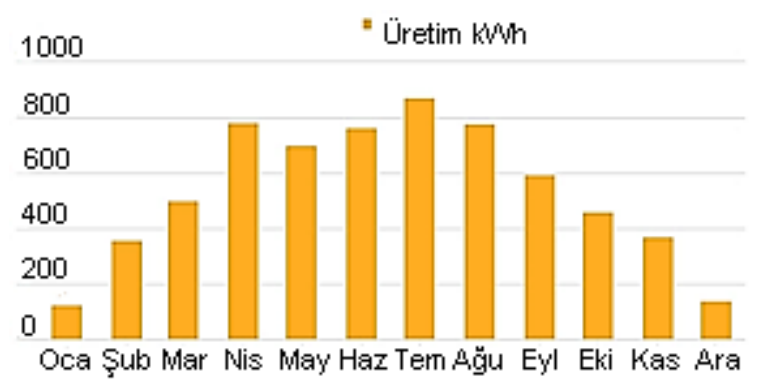

Figure 19. The results of PV system with Fronius web portal

\section{Comparison of Performance}

The technical performance simulation data of the PV system and real data are compared and reported in Table 12. It is seen in the table that the estimations made by the software examined in this study, are very close to the real results. However, the best energy production estimation has been made by PVSOL with 97 , 97\% accuracy. The Accuracy parameter in Table 11 is calculated from equation 1.

$$
\text { Accuracy }=\frac{\text { Simulated data }}{\text { Real data }} \times 100
$$

The performance ratio is the ratio of the actual and theoretically possible energy outputs. It is also defined as the global system efficiency with respect to the nominal installed power and the incident energy and is given in equation 2 .

Performance Ratio $(P R)=\frac{Y f}{Y r}$

In equation 2, Yf and $\mathrm{Yr}$ are defined as equation 2 and 3 respectively.

$Y \boldsymbol{f}=\frac{\text { Final energy output }(\mathrm{kWh})}{\text { Nominal DC power }(k W)}$

$Y r=\frac{\text { Total inplane irridiance }\left(\mathrm{kWh} / \mathrm{m}^{2}\right)}{\text { PV reference irridiance }\left(\mathrm{kW} / \mathrm{m}^{2}\right)}$

Equation 3 describes the final system yield (Yf, AC per rated DC) which is defined as the ratio of the PV system's actual energy output to its nominal DC power. The reference yield (Yr) is the ratio between total in-plane irradiance to that of the PV's reference irradiance. The PV reference irradiance at STC condition is equal to $1000 \mathrm{~W} / \mathrm{m}^{2}$.

Table 12. Comparison of energy production data

\begin{tabular}{|l|c|c|c|c|c|}
\hline $\begin{array}{l}\text { Performance } \\
\text { parameter }\end{array}$ & PV*SOL & PVGIS & PVsyst & RETScreen & $\begin{array}{c}\text { FRONIUS } \\
\text { Web portal }\end{array}$ \\
\hline $\begin{array}{l}\text { Annual PV energy } \\
(\text { kWh })\end{array}$ & 6306 & 6238,9 & 6274 & 6258,8 & 6436,54 \\
\hline Accuracy (\%) & 97,97 & 96,92 & 97,47 & 97,23 & 100 \\
\hline $\begin{array}{l}\text { Specific annual } \\
\text { yield ( }(\text { Wh/ } k \text { Wp) }\end{array}$ & 1236,5 & 1223,3 & 1177 & 1227,2 & 1262 \\
\hline $\begin{array}{l}\text { Performance } \\
\text { ratio (\%) }\end{array}$ & 83,7 & 82,8 & 82,63 & 83 & 84 \\
\hline
\end{tabular}

\section{Conclusions and Recommendations}

Various programs are used in the solar energy industry for the most appropriate design and analysis of PV systems. These programs make various predictions about the energy production and economic gains of PV systems by using meteorological data. The performance of PV systems is directly related to meteorological conditions, and the variability of climatic conditions makes it difficult to make accurate predictions.

In this study, the simulations of the $5,1 \mathrm{kWp}$ grid-connected PV system installed on the roof of Kocaeli University Faculty of Technology Faculty building are carried out using PV*SOL, PVsyst, RETScreen, and PVGIS software. The obtained simulation results are compared with the real data in terms of 
Annual PV Energy Production, Specific Annual Yield, and Performance Ratio criteria. According to the comparison results, it was concluded that $\mathrm{PV} * \mathrm{SOL}$ and PVsyst are evaluated as the most reliable software. PV*SOL estimated the actual energy production value with $97.97 \%$ accuracy and PV syst with $97.47 \%$ accuracy.

\section{References}

Yllmaz, M. C. (2019). The renewable energy transition in Turkey.

Sharma, R., \& Goel, S. (2017). Performance analysis of a 11.2 $\mathrm{kWp}$ roof top grid-connected PV system in Eastern India. Energy Reports, 3, 76-84.

Dey, D., \& Subudhi, B. (2020). Design, simulation and economic evaluation of $90 \mathrm{~kW}$ grid connected Photovoltaic system. Energy Reports, 6, 1778-1787.

Srivastava, R., \& Giri, V. K. (2016). Design of grid connected PV system using PVsyst. i-Manager's Journal on Electrical Engineering, 10(1), 14.

Milosavljević, D. D., Pavlović, T. M., \& Piršl, D. S. (2015). Performance analysis of A grid-connected solar PV plant in Niš, republic of Serbia. Renewable and Sustainable Energy Reviews, 44, 423-435.

Prasad, B. K. K., Reddy, K. P., Rajesh, K., \& Reddy, P. V. (2020). Design and simulation analysis of $12.4 \mathrm{kWp}$ grid connected photovoltaic system by using PVsyst software. International Journal of Recent Technology and Engineering, 8(5), 2859-2864.

Ahmed, O. A., Habeeb, W. H., Mahmood, D. Y., Jalal, K. A., \& Sayed, H. K. (2019). Design and performance analysis of $250 \mathrm{~kW}$ grid-connected photovoltaic system in iraqi environment using pvsyst software. Indonesian Journal of Electrical Engineering and Informatics (IJEEI), 7(3), 415421.

Sharma, S., Kurian, C. P., \& Paragond, L. S. (2018). Solar PV system design using PVsyst: a case study of an academic Institute. Paper presented at the 2018 International Conference on Control, Power, Communication and Computing Technologies (ICCPCCT).

Kumar, K. A., Sundareswaran, K., \& Venkateswaran, P. (2014). Performance study on a grid connected $20 \mathrm{kWp}$ solar photovoltaic installation in an industry in Tiruchirappalli (India). Energy for Sustainable Development, 23, 294-304.

Dondariya, C., Porwal, D., Awasthi, A., Shukla, A. K., Sudhakar, K., SR, M. M., \& Bhimte, A. (2018). Performance simulation of grid-connected rooftop solar PV system for small households: A case study of Ujjain, India. Energy Reports, 4, 546-553.

Barua, S., Prasath, R. A., \& Boruah, D. (2017). Rooftop solar photovoltaic system design and assessment for the academic campus using PVsyst software. International Journal of Electronics and Electrical Engineering, 5(1), 76-83.

PV*SOL, "PV*SOL Software." Online Availability: https://valentin-software.com/en/products/pvsol-premium/ Last Access date: 29 November 2021.
PVGIS, "PVGIS Software." Online Availability: https://ec.europa.eu/jrc/en/pvgis_Last Access date: 29 November 2021.

PVSyst, "PVSyst Software." Online Availability: https://www.pvsyst.com/fr/ Last Access date: 29 November 2021.

RETscreen software package online availability: https://www.nrcan.gc.ca/maps-tools-andpublications/tools/modelling-tools/retscreen/7465 Last Access date: 29 November 2021.

Kumar, N. M., Kumar, M. R., Rejoice, P. R., \& Mathew, M. (2017). Performance analysis of $100 \mathrm{kWp}$ grid connected Sipoly photovoltaic system using PVsyst simulation tool. Energy Procedia, 117, 180-189.

Application Note How to Design a SolarEdge System Using PVsyst online availability: http://docplayer.net/20962171Application-note-how-to-design-a-solaredge-system-usingpvsyst.html Last Access date: 29 November 2021.

Fronius solar web portal; https://www.solarweb.com/ Last Access date: 29 November 2021. 